\title{
Impact of Industrial Discharge on Aquatic Ecosystems of the Klodnica River with Reference to Water Framework Directive Objectives
}

\author{
Aleksandra Zgórska ${ }^{1 *}$, Jan Bondaruk ${ }^{1}$, Mariusz Dudziak ${ }^{2}$, Adam Hamerla ${ }^{1}$ \\ ${ }^{1}$ Central Mining Institute, Department of Water Protection, Katowice, Poland \\ ${ }^{2}$ Silesian University of Technology, Faculty of Energy and Environmental Engineering, Gliwice, Poland
}

Received: 26 August 2019

Accepted: 9 October 2019

\begin{abstract}
Commercial surface water classification is preliminarily based on physicochemical analyses. The ecotoxicological analyses performed during the research confirm that bioassays can support traditional monitoring as a useful tool for preliminary assess and predicting environmental damage. The problem of contaminant migration into the aquatic environment is particularly important in highly industrialized and urbanized areas, wherein rivers are constantly exposed to pollution due to anthropogenic action and for which, in accordance with the Water Framework Directive (WFD) recommendations, it is necessary to achieve good status and potential of the waters. Taking into account the above provisions, the ecotoxicological potential of surface water samples from the Kłodnica River has been assessed. During the research we used a biotest battery composed of organisms which represent three trophic levels of aquatic ecosystems: Vibri fischeri, Daphnia magna, and Lemna minor. Also, we performed physicochemical on-site analyses. Estimated values of selected physical and chemical indicators confirm the poor state of the Kłodnica. However, high toxic effect was obtained only in a few analysed samples. Moreover, is worth noting that within the study we found a relationship between the high salinity of river water samples and the response of exposed bioindicators.
\end{abstract}

Keywords: Kłodnica River, mine waters, water biomonitoring, industrial pollution, Water Framework Directive

\section{Introduction}

Protecting and improving the environment is an important part of achieving sustainable development and is vital in the long-term period. One of the most important documents in the field of water resources

*e-mail: azgorska@gig.eu management and by means of water protection is the European Union Water Framework Directive (WFD) [1]. This directive is a milestone in a history of water policy in Europe. The WFD establishes a common framework for a sustainable and integrated management in relation to a different types of water. The main purpose of the directive was to establish a framework for the protection of inland surface waters and groundwater. It will ensure that all inland and coastal waters, including 
aquatic and terrestrial ecosystems, should achieve good status by the end of 2015 . Within 15 years of the entry of WFD into force, the document was assisted by seven other EU directives relating to water policy. The WFD consists of different steps and monitoring procedures, which shall ensure that the "good ecological" and "good chemical" status of all European water bodies will be met in 2027. The constant access to "good quality of water" is especially important due to the fact that water is either an essential element necessary for life as well as an "organism of the economy" ensuring the functioning of many industries [2]. The water quality issue is especially important to Poland, which compared with other European countries has comparatively poor water resources [3]. Moreover, a large amount of pollutant discharged into the spring section of the Kłodnica River with outflows from WWTPs and mine water pose a significant problem for water users and consumers on the entire section of the river and finally pollute the Baltic Sea [4, 5]. The high level of industrialization and urbanization directly affects the quantity and quality of pollutants discharged into the environment. Anthropogenic activities introduce into the aquatic environment a large amount of toxic compounds that can cause irreversible damage [6-8]. In Poland, river water monitoring is mainly based on physicochemical analyses of the surface-water quality, and legal requirements do not include ecotoxicological evaluation. Physicochemical analyses are not able to detect all harmful substances that are present in the water. Moreover, it is difficult to predict the full response of living structures based only on the physicochemical parameters. Determining the full spectrum of pollutants and their metabolites, as well as taking into account the limitations of analytical and economic considerations, is simply impossible. Therefore, it is necessary to enrich the chemical analyses to the data from biomonitoring. The organisms accumulate large amounts of toxic compounds, even if their concentration in the environment is small and the time for reaction to a toxicant is relatively short. However, that reaction of the exposed organisms allows us to assess the toxicity of a single compound or a mixture, taking into account the effect of the synergistic or antagonistic interaction of components [8-10]. Therefore, the bioindication methods are the most effective tool for assessing the adverse effects and prevent environmental degradation. The physicochemical analyses of the pollutant should be completed with an ecotoxicological analyses in order to make the determination of ecological status of rivers [11, 12]. Such full analyses is important to ensure "good ecological" and "good chemical" status of water according to the requirements of the WFD. Taking into account the above provisions, the aim of this paper was to evaluate the usefulness of a toxicity classification system based on bioassays for routine monitoring of surface waters which are exposed to strong anthropogenic activities. Within the research the sensitivity of selected test species was evaluated. Also, the hazard classification system developed by Persoone et al. was used to assessed the ecotoxicological potential of raw water samples [13].

\section{Material and Methods}

\section{Study Area}

The study was conducted in Southern Poland, in the Silesian district. Research was carried out for the Kłodnica River basin located in the Upper Silesia Coal Basin Region (USCB). Sampling points were situated along the section of the Kłodnica from the river spring to the point situated above the Ostropka River estuary. The Kłodnica was chosen due to the fact that that the Kłodnica catchment receives wastewater from a large number of industrial and municipal companies. Therefore, water from the Kłodnica contains a wide range of contaminants, which can cause a wide spectrum of ecotoxic effects.

\section{Samples Collection}

Samples were collected from 16 sample points situated along the river. The choice of sampling points was made in order to capture the major sources of pollutants discharged into the river with both the wastewater from WWTP and mine water from four active coal mines. The location of sampling points is shown in Fig. 1. Therefore, within the study river water samples were collected from 13 samples points located both above and below the discharge points (Nos. 1-13). Until ecotoxicological analyses, water samples were stored at $4 \pm 2^{\circ} \mathrm{C}$. Due to the fact that the main goal of the research was the assessment of raw water samples, the samples were not filtered until the bioassays were conducted. Additionally, in order to assess the properties of mine waters as well as in order to estimate the impact of the high load of salinity on aquatic ecosystems, at discharges points for four mine water samples (D1-D4) the on-site physicochemical analyses were performed.

\section{Physicochemical Analyses}

On-site sampling the physicochemical analysis were performed. The scope of the analysis was set due to the nature of mine waters, which are characterized by elevated temperature value and high salinity level. Using a hand measuring probe (YSI model EcoSesne), all river water samples as well as samples of coal mine water discharged into the Kłodnica were analysed for: temperature $\left[{ }^{\circ} \mathrm{C}\right], \mathrm{pH}[-]$, total dissolved solids (TDS) $[\mathrm{g} / \mathrm{l}]$, conductivity $(\mathrm{SEC})[\mathrm{mS} / \mathrm{cm}]$ and salinity $[\mathrm{g} / \mathrm{l}]$. Additionally by the use of colorimetric assay MColortest (Merck), alkalinity [mmol/l] was measured. Moreover, in order to assess the presence of pharmaceuticals in an aquatic ecosystem the chemical analysis was extended by measuring the concentration of bisphenol A (BPA) in 


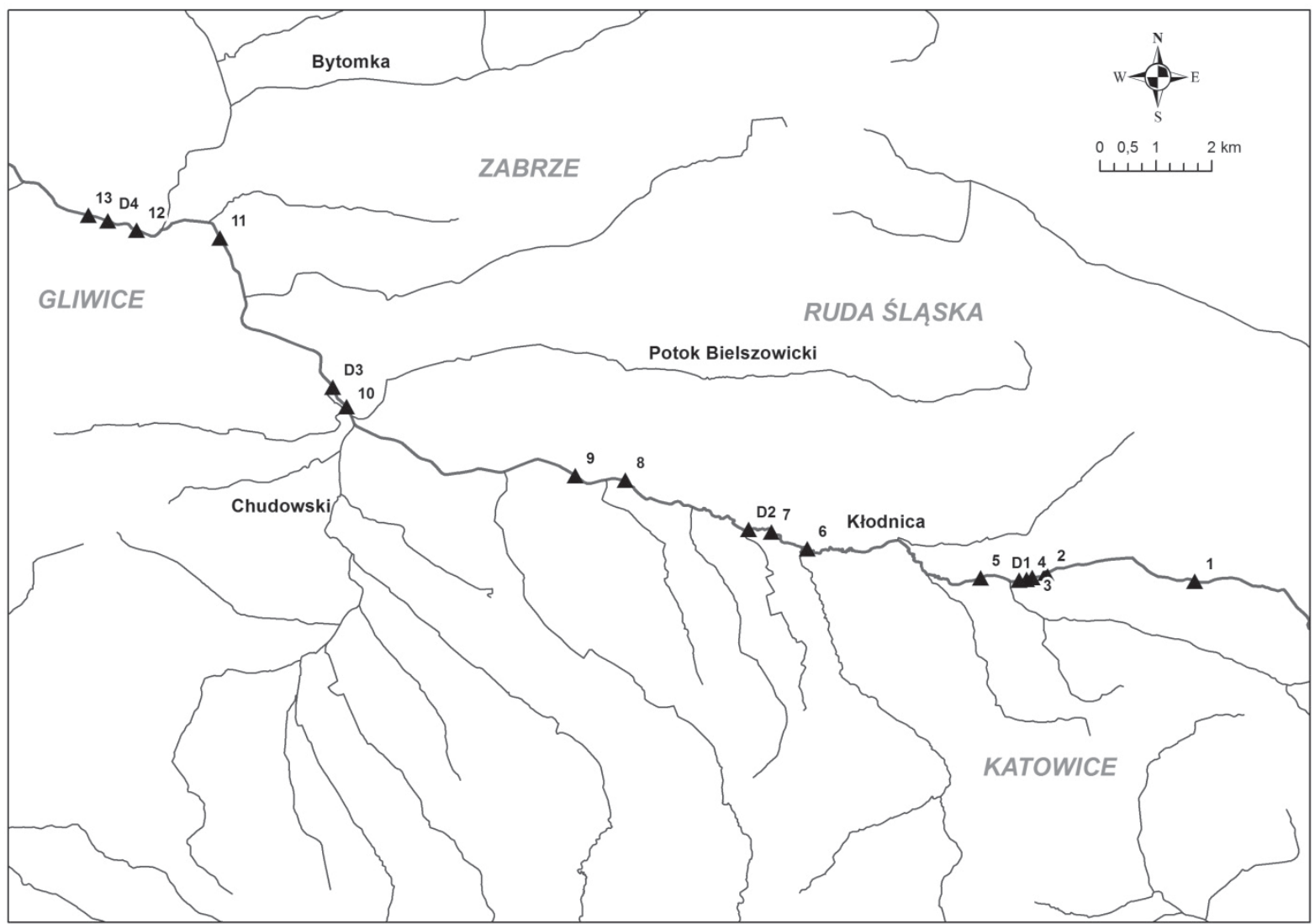

Fig. 1. Kłodnica river - location of sampling points (1 - spring section of the Kłodnica river; 2 - above the discharge from WWT; 3 - below the discharge from WWT; D1- discharge of mine water from KWK "Wujek" ruch "Śląsk"; 4 - below the discharge of mine water from "Wujek" coal mine; 5-below Ślepiotka river estuary; 6 - above Jamna river estuary; 7 - above the discharge of coal mine water; D2 - discharge of mine water from "Halemba" coal mine; 8 - above the discharge from WWT; 9 - below the discharge from WWT; 10 - below Potok Bielszowicki, above Bytomka river estuary; D3 - discharge of mine water from "Sośnica-Makoszowy" coal mine; 11 - below Czarniawka reiver estuary, above Bytomka river estuary; 12 - below Bytomka river estuary; D4- discharge of mine water from CZOK Gliwice; 13 - below the discharge of mine water from CZOK Gliwice).

river water samples (laboratory analyses). Measurement of this chemical indicator allowed us to assess the impact of wastewater discharges from WWTP on the quality of river water.

\section{Ecotoxicological Tests}

The ecotoxicological assessment of river water samples was performed by the use of a biotest battery consisting of three bioassays. To take into consideration the realities of the functioning ecological systems in the study area the ecotoxicological analysis was based on a biotest battery consisting of organisms that belong to three different aquatic ecosystem trophic levels: decomposers (bacteria), producers (higher plants) and consumers (crustaceans). Key information about the tests used during the ecotoxicological analyses are summarized in Table 1.

\section{Lemna Minor Growth Inhibition Test}

The growth inhibition test with Lemna minor was performed according to OECD standard procedure [14].
According to recommendations for the preparation of environmental samples (surface water samples), the test was performed without dilution for the raw water samples in triplicate. The growth inhibition value was estimated after $168 \mathrm{~h}$ of exposure by calculation of a frond number. The colour of fronds as well as length and condition of roots was also assessed. The toxic effect was expressed as a percentage of root and plant growth inhibition.

\section{Daphnia Magna Immobilization Test}

The test was performed according to OECD standard procedure No. 202 [15] and carried out using crustacean neonates (time living $<24 \mathrm{~h}$ ). According to recommendations for the preparation of environmental samples (surface water samples), the test was performed without dilution for the raw water samples in triplicate. The duration of the test was 24 and $48 \mathrm{~h}$. Respectively, after 24 and $48 \mathrm{~h}$ of exposure the number of immobilized organisms was recorded. For each test sample the toxic effect was expressed as a percentage of immobilization. 
Table 1 . Characteristics of the biotest battery.

\begin{tabular}{|c|c|c|c|c|c|c|}
\hline Trophic level & Organisms & Test name & Endpoint & $\begin{array}{c}\text { Test } \\
\text { duration }\end{array}$ & $\begin{array}{l}\text { Type } \\
\text { of test }\end{array}$ & $\begin{array}{l}\text { Compatibility with } \\
\text { standard }\end{array}$ \\
\hline Producers & Lemna minor & OECD 221 & Growth inhibition & $168 \mathrm{~h}$ & chronic & $\begin{array}{c}\text { SS } 028213 \\
\text { AFNOR XPT90-337 } \\
\text { EPA 712-C-96-156 } \\
\text { ASTM E1415-91 } \\
\text { OECD } 221\end{array}$ \\
\hline Consumers & $\begin{array}{l}\text { Daphnia } \\
\text { magna }\end{array}$ & OECD 202 & Immobilisation & $24 \mathrm{~h}$ & acute & $\begin{array}{c}\text { DIN 38412 P11 } \\
\text { EPA 600/4-90-027F } \\
\text { EPS 1/RM/11 } \\
\text { AFNOR XP T90-380 } \\
\text { ISO 6341:1996 } \\
\text { PN-EN ISO } \\
\text { 6341:2002 OECD } 202 \\
\text { ASTM E1193-97 } \\
\text { ISO 10706:2000 } \\
\text { OECD } 211 \\
\text { AFNOR NF T90-37 }\end{array}$ \\
\hline Decomposers & Vibrio fischeri & MICROTOX $^{\circledR}$ & $\begin{array}{l}\text { Bioluminescence } \\
\text { inhibition }\end{array}$ & $15 \mathrm{~min}$ & acute & $\begin{array}{c}\text { EPS, } 1 / \mathrm{RM} / 24, \\
\text { ISO } 11348: 1,2 \text { i } 3, \\
\text { DIN, } 38412 \\
\text { PN-EN ISO, } \\
11348-2002\end{array}$ \\
\hline
\end{tabular}

Vibrio Fischeri-Microtox Procedure

The test was carried out using a Microtox 500 analyzer. Within the test, reagents and test samples were handled according to the $81,9 \%$ Screening Test procedure described in the Microtox manual [16]. Test durations were 5 and 15 minutes. Respectively, after $5 \mathrm{~min}$ and $15 \mathrm{~min}$ of exposure the inhibition of bioluminescence for each analysed sample was recorded. For each exposure time the toxic effect was expressed as a percentage inhibition of bioluminescence. All calculations in the assay were performed using the standard Microtox software (MicrotoxOmni).

\section{Toxicity Classification System}

The obtained ecotoxicity data has been expressed as a percentage effect (PE), which depends on the specific effect criteria, defined in a section above respectively for each assay. The ecotoxicity data has been classified according to the hazard classification system for surface and groundwater samples developed by the Persoone team (Table 2) [13].

To indicate the quantitative importance of the toxicity obtained in individual bioassays, for each hazard class a weight score was calculated. The weight score calculation procedure assumed allocation of a test score for each bioassay of the battery. The weight scores were assigned based on assumptions present in Table 3. Final class weight scores were calculated using

Table 2. Hazard classification system for natural waters proposed by Persoone et al. 2003 [13].

\begin{tabular}{|c|c|c|c|}
\hline PE & Hazard class & Hazard & Symbol \\
\hline$\leq 20 \%$ & Class I & No acute hazard \\
\hline $20 \% \leq \mathrm{PE}<50 \%$ & Class II & Slight acute hazard & Acute hazard \\
\hline $50 \% \leq \mathrm{PE}<100 \%$ & Class III & High acute hazard & \\
\hline $\mathrm{PE} 100 \%$ in at least one test & Class IV & Very high acute hazard & \\
\hline $\mathrm{PE} 100 \%$ in all tests & Class V &
\end{tabular}


Table 3. Calculation of weight score based on methodology developed by Persoone et al. [13].

\begin{tabular}{|c|c|}
\hline Score & Effect result of each ecotoxicological test \\
\hline 0 & No "significant" toxic effects \\
\hline 1 & Significant toxic effect $<$ PE 50 \\
\hline 2 & Toxic effect $>$ PE50 $<$ PE 100 \\
\hline 3 & PE 100 \\
\hline
\end{tabular}

the following formulas: class weight score $=\left(\sum\right.$ all test scores $) / \mathrm{n}$ ( $\mathrm{n}=$ number of test performed); class weight score in $\%=($ class score $) /($ maximum class weight score $)$ $\mathrm{x} 100$ [13].

\section{Results and Discussion}

The results of physicochemical analyses confirm that the Kłodnica is highly affected by municipal and mining activities. Each discharge of wastewater and mine waters into the river caused an increase in concentrations of pollution indicators such as: temperature, conductivity, total dissolved solids, salinity, and alkalinity. For example, for sample points located directly upstream and downstream of the mine water discharges, the following conductivity fluctuations were observed respectively: from $0,83 \mathrm{mS} / \mathrm{cm}$ (No. 3) to $6,27 \mathrm{mS} / \mathrm{cm}$ (No. 4) for mine water discharge from KWK Wujek ruch Śląsk (D1), and from 4,36 mS/cm (No. 7) to $13,57 \mathrm{mS} / \mathrm{cm}$ (No. 8) for mine water discharge from KWK Halemba (D2). Below the discharge of mine waters from KWK Sośnica-Makoszowy (D3) and CZOK Gliwice (D4), conductivity value increases respectively to 16,27 $\mathrm{mS} / \mathrm{cm}$ (No. 10) and 13,45 mS/cm (No. 13). Each mine water inflow led to increased temperature of river water, which ranged from $13^{\circ} \mathrm{C}$ (No. 2) to $21^{\circ} \mathrm{C}$ (No. 10). Moreover, location along the river of other emission sources, closely related with increasing pollution load discharged into the river, directly affected the growth of water sample alkalinity. The alkalinity value recorded for the first sampling point (No. 1) amounted to $3,05 \mathrm{mmol} / \mathrm{l}$, while in the last sampling point the alkalinity value reached $8,5 \mathrm{mmol} / 1$ (No. 13). Alkalinity of mine waters introduced into the river amounted respectively to: $3,5 \mathrm{mmol} / \mathrm{l}$ (D1); $6,5 \mathrm{mmol} / \mathrm{l}$ (D2); 7,5 mmol/1 (D3) and 8,5 mmol/1 (D4). The results of physicochemical analysis of raw mine water samples are summarized in the table below (Table 4).

The discharge of mine waters contributed to the increase in the salinity of the Kłodnica. Particularly, the salinity value increased after mine water discharge respectively from $0,4 \mathrm{~g} / \mathrm{l}$ (No. 3) to $3,4 \mathrm{~g} / \mathrm{l}$ (No. 4) for discharge of mine waters from KWK Wujek ruch Śląsk (D1) and from 2,3 (No. 7) to 7,8 g/l (No. 8) for discharge of mine waters from KWK Halemba (D2). Below the discharge of mine waters from KWK Sośnica-Makoszowy (D3) and CZOK Gliwice (D4), the river water salinity reached 9,6 g/1 (No. 11). The results of physicochemical analyses of river samples are shown in Fig. 2.

The study results confirm the poor chemical status of the Kłodnica. Except for the samples collected from the spring river section (sample points located prior to wastewater discharges), any of the analysed sample do not meet the requirements for the surface water set by Articles of the Water Law Act (Dz.U.2017.1566) [17]. For most pollution indicators the limit values were exceeded.

Additionally, enrichment physicochemical analysis of the measurement of BPA concentration in river water samples indicated the relationship between discharge from WWTP and the increasing concentration of

Table 4. Characteristics of mine water discharged to the Kłodnica River.

\begin{tabular}{|c|c|c|c|c|c|}
\hline \multirow{2}{*}{ Parameter } & \multirow{2}{*}{ Unit } & \multicolumn{4}{|c|}{ The entrepreneur responsible for mine water discharge } \\
\cline { 3 - 6 } & & $\begin{array}{c}\text { KWK “Wujek" ruch } \\
\text { „Sląsk" }\end{array}$ & $\begin{array}{c}\text { KWK } \\
\text { "Halemba” }\end{array}$ & $\begin{array}{c}\text { KWK } \\
\text { "Sośnica-Makoszowy” }\end{array}$ & CZOK Gliwice \\
\hline Sample No & - & $\mathrm{D} 1$ & $\mathrm{D} 2$ & $\mathrm{D} 3$ & D4 \\
\hline \multirow{2}{*}{ Geographical coordinates } & $\mathrm{X}$ & 262426.63 & 263321.86 & 266484.65 & 268963.22 \\
\cline { 3 - 6 } & $\mathrm{Y}$ & 494855.16 & 491022.03 & 482184.49 & 478139.39 \\
\hline Ambient temperature & ${ }^{\circ} \mathrm{C}$ & 20,0 & 27,0 & 26,0 & 26,0 \\
\hline Water temperature & ${ }^{\circ} \mathrm{C}$ & 19,9 & 23,9 & 21,0 & 19,5 \\
\hline SEC & $\mathrm{mS} / \mathrm{cm}$ & 13,15 & 23,35 & 9,22 & 14,86 \\
\hline TSD & $\mathrm{g} / 1$ & 8,3 & 14,7 & 5,8 & 9,4 \\
\hline Salinity & $\mathrm{g} / 1$ & 7,6 & 14,1 & 5,2 & 8,7 \\
\hline $\mathrm{pH}$ & - & 7,40 & 6,55 & 7,44 & 7,25 \\
\hline Alkalinity & $\mathrm{mmol} / 1$ & 4,5 & 10,0 & 7,2 & 8,3 \\
\hline
\end{tabular}




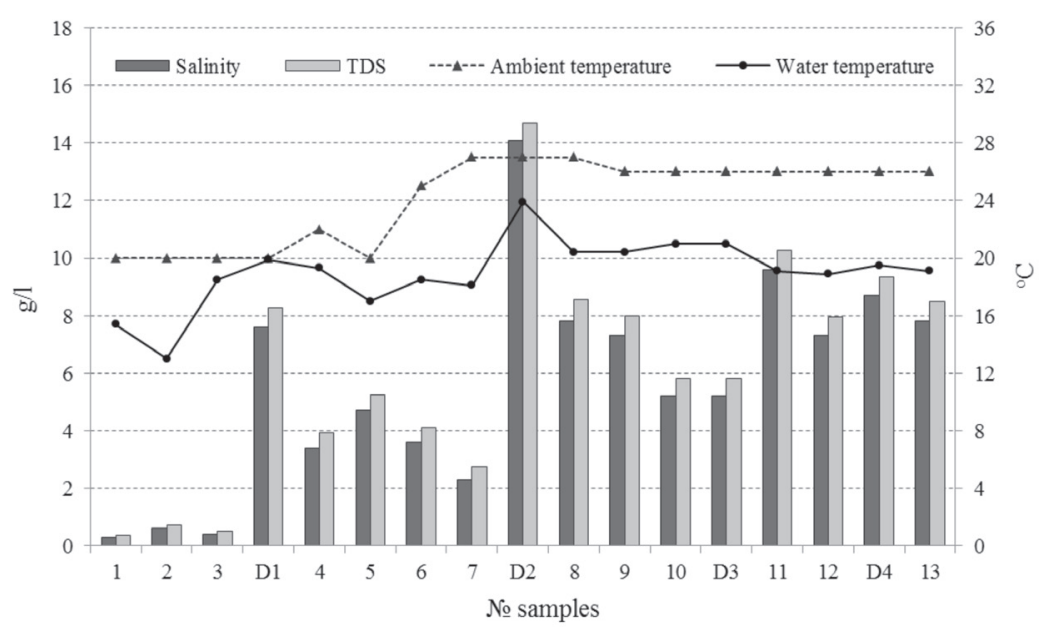

Fig. 2. Impact of mine water discharges on the physicochemical properties of the Kłodnica River (abbreviations are defined in the description of Fig. 1).

pharmaceuticals (BPA) in surface water. The BPA concentration range in analysed samples was maintained in the range from $0 \mathrm{ng} / \mathrm{l}$ (No. 2) to $141 \mathrm{ng} / \mathrm{l}$ (No. 5). A significant increase of BPA concentration in water samples was recorded for the sampling points located directly downstream of the discharge into the receiver of treated wastewater from WWTP. For example, the impact of municipal wastewater to surface water quality can be observed for measuring points 2 and 3, located respectively above and below the discharge point from WWTP, for which the BPA concentration in water increased from 0ng/l (No. 2) to $76 \mathrm{ng} / \mathrm{l}$ (No. 3).

The results of ecotoxicological analyses are shown in Table 5. The bioassay results show that analysed samples do not cause toxic effects with respect to freshwater crustaceans (Daphnia magna). The relationship between induced ecotoxicological effects and point of waste water discharges can be found only in the case of the phytotoxicity test, for sampling points 4 and 11, for which the growth inhibition of Lemna minor amounted to respectively $25 \%$ and $50 \%$. A high level of growth inhibition of Lemna minor root was

Table 5. Results of ecotoxicological analyses.

\begin{tabular}{|c|c|c|c|c|c|c|c|c|c|c|}
\hline \multirow{3}{*}{$\begin{array}{l}\text { Samples } \\
\text { Number }\end{array}$} & \multicolumn{3}{|c|}{ Bacterial (Vibrio fischeri) } & \multicolumn{3}{|c|}{$\begin{array}{l}\text { Higher pants** } \\
\text { (Lemna minor L.) }\end{array}$} & \multicolumn{3}{|c|}{$\begin{array}{c}\text { Crustaceans** (Daphnia } \\
\text { magna })\end{array}$} & \multirow{3}{*}{ Hazard Class } \\
\hline & \multicolumn{2}{|c|}{$\%$ effects $(\mathrm{PE})$} & \multirow{2}{*}{$\begin{array}{l}\text { Test } \\
\text { score }\end{array}$} & \multicolumn{2}{|c|}{$\%$ effects (PE) } & \multirow{2}{*}{$\begin{array}{l}\text { Test } \\
\text { score }\end{array}$} & \multicolumn{2}{|c|}{$\%$ effects (PE) } & \multirow{2}{*}{$\begin{array}{l}\text { Test } \\
\text { score }\end{array}$} & \\
\hline & $5 \mathrm{~min}$ & $15 \mathrm{~min}$ & & Plant & Root & & $24 \mathrm{~h}$ & $48 \mathrm{~h}$ & & \\
\hline № 1 & $-12,8$ & $-17,0$ & 0 & 0 & $-122,0$ & 0 & 0 & 0 & 0 & Class I \\
\hline № 2 & $-11,7$ & $-20,5$ & 0 & 0 & 50,0 & 2 & 0 & 0 & 0 & Class II \\
\hline № 3 & $-19,4$ & $-25,1$ & 0 & 0 & $-33,0$ & 0 & 0 & 0 & 0 & Class I \\
\hline № 4 & $-30,4$ & $-38,0$ & & 25,0 & $-128,0$ & 1 & 0 & 0 & 0 & Class II \\
\hline № 5 & $-3,6$ & $-11,5$ & 0 & 0 & $-72,0$ & 0 & 0 & 0 & 0 & Class I \\
\hline № 6 & $-0,6$ & $-7,5$ & 0 & $-25,0$ & $-300,0$ & 0 & 0 & 0 & 0 & Class I \\
\hline № 7 & $-17,2$ & $-30,0$ & 0 & 0 & $-128,0$ & 0 & 0 & 0 & 0 & Class I \\
\hline № 8 & $-7,3$ & $-13,8$ & 0 & 0 & $-156,0$ & 0 & 0 & 0 & 0 & Class I \\
\hline № 9 & $-36,3$ & $-51,0$ & 0 & 0 & $-72,0$ & 0 & 0 & 0 & 0 & Class I \\
\hline № 10 & $-9,2$ & $-22,7$ & 0 & $-25,0$ & $-156,0$ & 0 & 0 & 0 & 0 & Class I \\
\hline № 11 & $-12,8$ & $-30,5$ & 0 & 50,0 & 83,0 & 2 & 0 & 0 & 0 & Class III \\
\hline № 12 & $-7,5$ & $-22,0$ & 0 & 0 & 89,0 & 2 & 0 & 0 & 0 & Class III \\
\hline № 13 & $-6,82$ & $-13,2$ & 0 & 0 & 56,0 & 2 & 0 & 0 & 0 & Class I \\
\hline
\end{tabular}

* Simplified methodology based on OECD guidelines No 221; ** Simplified methodology based on OECD guidelines No 202 


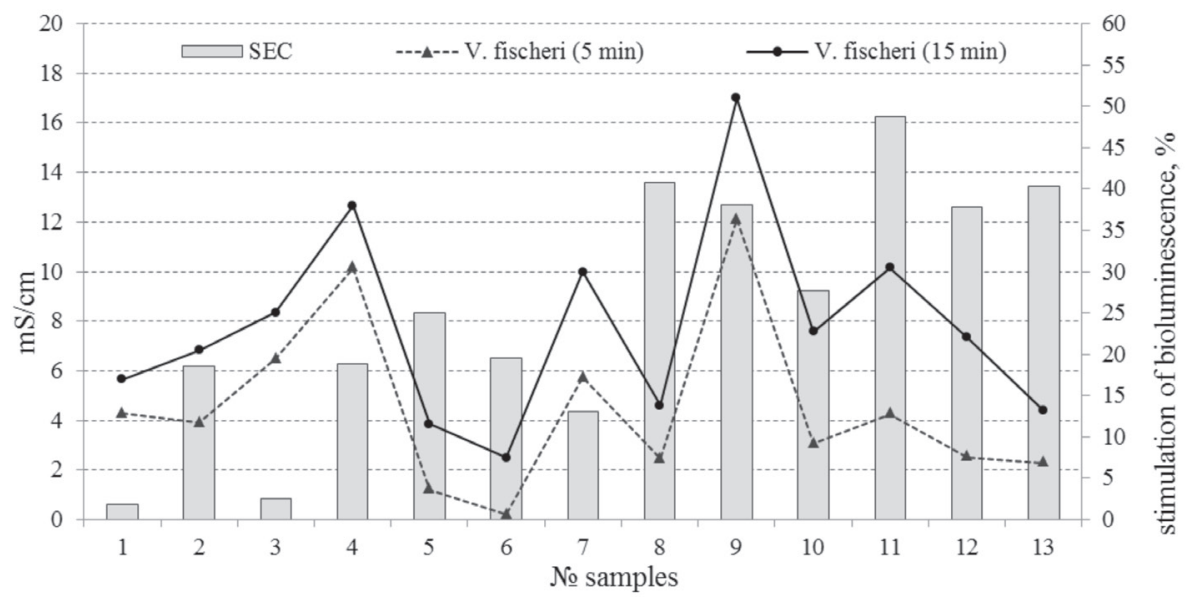

Fig. 3. Correlation between MICROTOX test results and water sample conductivity.

observed for samples 11-13. It should be noted that the highest inhibition values were observed for samples collected from the points located in the final section of study area (56\% for sample 13 and $89 \%$ for sample 12$)$. Obtained results confirm the presence in the aquatic environment of high pollution loads, which as a result of ongoing interaction can caused cumulative toxic effects.

The analysed water samples did not affect the inhibition of Vibrio fischeri bioluminescence. However, test results obtained after 5 and 15 minutes of exposure show that environmental changes caused by human activity affect the stimulation of the natural metabolic processes of tested bacteria (Vibrio fischeri) in the range $7,5 \%$ (No. 6) to $51,0 \%$ (No. 9). The relationship between the stimulation of bioluminescence of Vibrio fischeri and the conductivity values is shown in Fig. 3. As demonstrated in the literature [18], the stimulation of bioluminescence is probably caused by the presence in the environment of high concentrations of potassium $\left(\mathrm{K}^{+}\right)$and sodium $\left(\mathrm{Na}^{+}\right)$ ions. High potassium concentration plays a key role in the process of transcription of bioluminescence genes of $P$. phosphoreum, and often is achieved by a high sodium concentration through the $\mathrm{Na} / \mathrm{K}$ pomp [18]. Therefore, the observed effect could be caused by high concentrations of potassium and sodium ions present in the mine waters in large quantities. The phytotoxicty and MICROTOX test results confirm that the Kłodnica has an ecotoxicological potential to aquatic organisms closely connected with the place and scale of industrial discharges. The MICROTOX test results confirmed that the used bioassay is a sensitive method that allows us to assess the potential environmental damage caused by municipal and industrial discharges. The effectiveness of the MICROTOX technique has been widely described in the literature [19-21].

According to the hazard classification methodology, most of analysed samples were classified as non-toxic (Class I). Due to the phytotoxicity test results, two of the analysed samples were classified as Class II (Nos.
2 and 4), and another two were classified as Class III (Nos. 11 and 12) (Table 5).

\section{Conclusions}

Research results clearly indicate that disposal of mine water from coal mines located in the study area (USCBR) is associated with pollution-related changes to the water quality properties - particularly with respect to its physicochemical parameters. Mine waters discharged into the Kłodnica within the study area at four points (KWK Wujek ruch Śląsk, KWK Halemba, KWK Sośnica-Makoszowy and CZOK Co.) caused significant modification to water chemistry. The physicochemical properties of water, downstream from each mine, were different. However, analysing the obtained data, three common trends can be found: water downstream from the discharge was more saline and had higher conductivity and TDS concentration.

Results of physicochemical analyses indicate that each identified mine water discharge could be considered water pollution, which can cause irreversible modification in water chemistry. High levels of contaminants present in mine waters in combination with water drainage system who determines the "jumping" dosage of pollutants into aquatic ecosystems may cause serious stress to an aquatic ecosystem. The negative impact of salinity on aquatic ecosystems has been the subject of previous studies [22, 23]. Obtained bioassay results confirm that the Kłodnica has a toxic potential closely connected with the place and scale of industrial discharge. The MICROTOX test results confirmed that the used bioassay is a sensitive method that allows us to assess the potential environmental damage caused by municipal and industrial discharges. Higher bioluminescence stimulation coincide with the area of influence of mine water discharges from active coal mines like KWK Wujek, KWK Halemba, and KWK Sośnica-Makoszowy, and from central mine 
dewatering company (e.g., CZOK Gliwice). The results indicate that the MICRITOX bioassay is an appropriate tool to permit risk assessment studies at the screening level.

The regulations concerning the discharge of mine water into rivers currently fails to impose any discharge salinity limits on mine waters or on any other significant type of pollution (e.g., major cation or anion) [24]. The area of legal regulation in respect to any discharge of mine water requires further examination. In view of the study results, as well as bearing in mind the guidelines of the WFD in particular, the achievement of good water status of the Kłodnica, there is still a need for further research to provide evidence for authorities on direct and cumulative impacts of water chemistry changes on aquatic ecosystems - particularly for waterways with high conservation value. Due to the poor chemical and ecological state of the Kłodnica and the risk of not achieving the required environmental effects, national and local authorities should take all necessary steps to counteract the untreated municipal and industrial discharges by installing adequate wastewater treatment systems. Furthermore, new permission for the industrial users should be given only for companies, which through the application of appropriate treatment techniques meet environmental standards in terms of quality of discharged wastewater. Moreover, it is important to point out that the presence of heavy metals and radionuclides, which are often present in mine water at high concentrations, has not been considered during the analyses. Therefore, both the assessment of the quality of water for the presence of these impurities, as well as evaluation of their potential negative environmental impact should be the subject of further research.

\section{Acknowledgements}

The work was financed by the Ministry of Science and High Education, Republic of Poland, under research grant No. 11310155-340.

\section{Conflict of Interest}

The authors declare no conflict of interest

\section{References}

1. DIRECTIVE 2000/60/EC OF THE EUROPEAN PARLIAMENT AND OF THE COUNCIL of 23 October 2000 establishing a framework for Community action in the field of water policy (Water Framework Directive).

2. CARVALHO L., MACKAY E.B., CARDOSO A.C., BAATTRUO-PEDERSEN A., BIRK S., BLACKSTOCK K.L., BORICS G., BORJA A., FELD CH., FERREIRA M.T., GLOBEVNIK L., GIZZETTI B., HENDRY S., HERING D., KELLY M., LANGAAS S., MEISSNER
K., PANAGOPOULOS Y., PENNING E., ROUILLARD J., SABATER S., SCHMADTJE U., SPEARS B., VENOHR M., VAN DE BUND W., SOLHEIM A.L. Protecting and restoring European's waters: An analysis of the future development needs of the Water Framework Directive. Science of the Total Environment 658, 228, 2019.

3. ABSALON D., MATYSIK M. Changes in water quality and runoff in the Upper Oder River Basin. Gemorphology 92, 106, 2007.

4. KAZA M., BOCZEK-MANKIEWICZj., IZYDORCZYK K., SAWICKI J. Toxicity Assessment of Water Samples from Rivers in Central Poland Using a Bettery of Microbiotest - a Pilot Studies. Polish Journal of Environmental Study 16 (1), 81, 2007.

5. MANKIEWICZ-BOCZEK J., JAWECKI-NAŁĘCZ G., DROBNIEWSKA A., KAZA M., SUMOROK B., IZYDORCZYK K., ZALEWSKI M., SAWICKI J. Application of microbiotest battery for complete toxicity assessment of rivers. Ecotoxicology and Environmental Safety, 71, 830, 2008.

6. PANKIEWICZ-SPERKA M., STAŃCZYK K., PŁAZA G.A., KWASNIEWSKA J., NAŁECZ-JAWECKI G. Assessment of the chemical, microbiological and toxicological aspects of post-processing water from underground coal gasification. Ecotoxicology and Environmental Safety 108, 249, 2014.

7. RUALES-INZUNZA J., GREEN-RUIZ C., ZAVALANAVĂREZ M., SOTO-JIMÉNEZ M. Biomonitoring of $\mathrm{Cd}, \mathrm{Cr}, \mathrm{Hg}$ and $\mathrm{Pb}$ in the Baluarte River basin associated to a mining area (NW Mexico). Science of Total Environment 409, 3527, 2011.

8. SULLIVAN R., WRIGHT I., RENSHAW A., WILKS M. The assessment of impact from mining wastes on water quality and aquatic ecosystems using freshwater macroinvertebrate communities and novel bio-assay tests. $7^{\text {th }}$ Australian Stream management Conference, Townsville, Queensland, 1, 2014.

9. GUPTA S.K., CHABUKDHARA M., KUMAR P., SINGH J. Evaluation of ecological risk of metal contamination in river Gomti, India: A biomonitoring approach. Ecotoxicology and Environment Safety 110, 49, 2014.

10. WU N., DONG X., LIU Y., WANG CH., BAATTRUOPEDERSEN A., RIIS T. Using river microalgae as indicators for freshwater biomonitoring: Review of published research and future direction. Ecological Indicators 81, 124, 2017.

11. LAINI A., BOLPAGNI R., CANCELLARIO T., GUARESCHI S., RACCHETTI E., VIAROLI P. Testing the response of macroinvertebrate communities and biomonitoring indices under multiple stressors in a lowland river. Ecological Indicators 90, 47, 2018.

12. STUBBINGTON R., CHADD R., CID N., CSABAI Z., MILIŠA M., MORAIS M., MUNNĚ A., PAŘIL P., PEŠIČ v., TZIORTZIS I., VERDONSCHOT R., DATRY T. Biomonitoring of intermittent rivers and ephemeral stream in Europe: Current practice and priorities to enhance ecological status assessments. Science of the Total Environment 618, 1096, 2018.

13. PERSOONE G., MARSALEK B., BLINOVA I., TÖRÖKNE A., ZARINA D., MANUSADZIANAS L., NALECZ-JAWECKI G., TOFAN L., STEPANOVA N., TOTHOLA L., KOLAR B. A Practical and User-Friendly Toxicity Classification System with Microbiotests for Natural Waters and Wastewaters.Wiley Interscience, DOI 10.1002/tox.10141, 2003. 
14. OECD Guidelines for Testing of Chemicals. Test No. 221 Lemna sp. Growth Inhibition test, 2006.

15. OECD Guidelines for Testing of Chemicals. Test No. 202 Daphnia sp. Acute Immobilisation test, 2004.

16. AZUR ENVIRONMENTAL: Microtox Standard Operational Procedure, 1991.

17. The Act of 20 July 2017 Water Law Act [Dz.U.2017.1566].

18. CAŇEDO-ARGÜELLES M., BUNDSCHUH M., GUTIĔRREZ-CĂNOVAS C., KEFFORD B.J., PRAT N., TROBOJO R., SCHÄFER R.B. Effects of repeated salt pulses on ecosystem structure and functions in a stream mesocom. Science of the Total Environment 476, 634, 2014.

19. OCAMPO-DUQUE W., SIERRA J., FERRÉ-HUGUET N., SCHUHMACHER M., DOMINGO J.L. Estimating the environmental impact of micro-pollutant in the low Ebro River (Spain): An approach based on screening toxicity with Vibrio fischeri. Chemosphere 72, 715, 2008.

20. ZHANG L., LI Q., CHEN L., ZHANG A., HE J., WEN Z., WU L. Toxicity of surface water from Huangpu River to luminous bacteria (Vibrio qinghaiensis Sp. Q67) abd zebvra fish (Danio rerio) embryos. Ecotoxicology and Environmental Safety 112, 137, 2015.
21. DIZER H., WITTEKINDT E., FISCHER B., HANSEN P.-D. The cytotoxic and genotoxic potential of surface water and wastewater effluents as determined by bioluminescence, umu-assays and selected biomarkers. Chemosphere 46, 225, 2002.

22. OLKOWSKA E., KUDŁAK B., TSAKOVSKI S., RUMAN M., SIMEONOV V., POLKOWSKA Z. Assessment of the water quality of Kłodnica River catchement using selforganizing maps. Science of the Total Environment 476, 477, 2014.

23. LEWIN I., SMOLIŃSKI A. Rare and vulnerable species in the mollusc communities in the mining subsidence reservoirs of an industrial area (The Katowice Upland, Upper Silesia, Southern Poland). Limnologica 36, 181, 2006.

24. WRIGHT I. Coal mine 'dewatering" of saline wastewater into NSW streams and rivers: a growing headache for water pollution regulators. $6^{\text {th }}$ Australian Stream Management Conference, Canberra, Australian Capital Territory, 1, 2011. 
